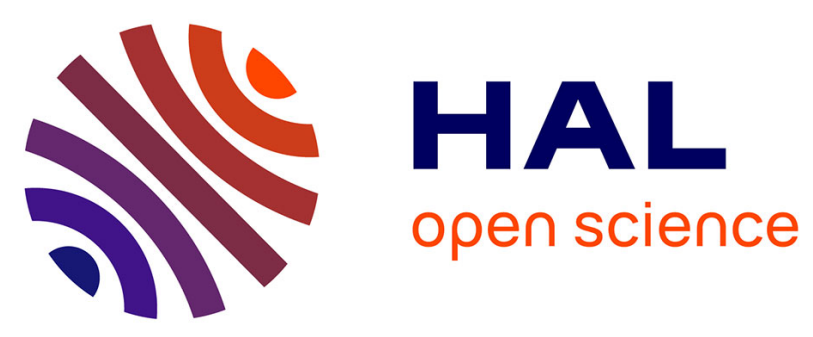

\title{
Land use legacies on forest understory vegetation and soils in the Mediterranean region: Should we use historical maps or in situ land use remnants?
}

\author{
Juliet Abadie, Catherine Avon, Jean-Luc Dupouey, Jean-Michel Lopez, \\ Thierry Tatoni, L. Bergès
}

\section{To cite this version:}

Juliet Abadie, Catherine Avon, Jean-Luc Dupouey, Jean-Michel Lopez, Thierry Tatoni, et al.. Land use legacies on forest understory vegetation and soils in the Mediterranean region: Should we use historical maps or in situ land use remnants?: Should we use historical maps or in situ land use remnants?. Forest Ecology and Management, 2018, 427, pp.17-25. 10.1016/j.foreco.2018.05.050 . hal-02080264

\section{HAL Id: hal-02080264 https://hal.science/hal-02080264}

Submitted on 26 Mar 2019

HAL is a multi-disciplinary open access archive for the deposit and dissemination of scientific research documents, whether they are published or not. The documents may come from teaching and research institutions in France or abroad, or from public or private research centers.
L'archive ouverte pluridisciplinaire HAL, est destinée au dépôt et à la diffusion de documents scientifiques de niveau recherche, publiés ou non, émanant des établissements d'enseignement et de recherche français ou étrangers, des laboratoires publics ou privés. 


\title{
Land use legacies on forest understory vegetation and soils in the Mediterranean region: Should we use historical maps or in situ land use remnants?
}

\author{
Juliet Abadie $^{\mathrm{a}, *}$, Catherine Avon ${ }^{\mathrm{b}}$, Jean-Luc Dupouey ${ }^{\mathrm{c}}$, Jean-Michel Lopez ${ }^{\mathrm{a}}$, Thierry Tatoni ${ }^{\mathrm{d}}$, \\ Laurent Bergès ${ }^{\mathrm{e}}$ \\ a Irstea, UR RECOVER, 3275, route de Cézanne, CS 40061, F-13182 Aix-en-Provence Cedex 5, France \\ ${ }^{\mathrm{b}}$ Semperfloris, Place de la République, F-07000 Privas, France \\ ${ }^{\mathrm{c}}$ University of Lorraine, AgroParisTech, INRA, UMR Silva, Rue d'Amance, F-54280 Champenoux, France \\ d UMR IMBE, Aix Marseille Université, Avignon Université, CNRS, IRD, Campus de St-Jérôme, F-13397 Marseille Cedex 20, France \\ e Université Grenoble Alpes, Irstea, UR LESSEM, 2 rue de la Papeterie BP 76, F-38402 St-Martin-d'Hères, France
}

\begin{abstract}
A B S T R A C T
How to move forward if we cannot understand our present from our past? The same applies for the study of ecosystems. Evidence of ecological legacies in temperate post-agricultural forests has been provided on soil physico-chemical properties and understory vegetation richness and composition, which led to distinguish ancient and recent forests. However, no land use legacies dating back more than 50 years have been reported in Mediterranean forests. The definition of ancient and recent forests usually relies on a threshold date, most often provided by historical maps. In France, the Etat-Major map is the most precise, with a relatively high resolution and drawn over the whole country with a standardised method. However, the use of historical maps only for studying land use legacies in forest is questionable in a Mediterranean context characterised by a traditional agro-sylvo-pastoral system. Using a historical ecology approach, our purpose was to examine the legacies of various former land uses on soil and understory vegetation in Mediterranean forests and to compare the relevance of two historical sources: 1860 land use map (map-based PLU) and remnants recorded in the field (in situ PLU remnants). In the Regional Natural Park of Luberon (French Mediterranean area), we inventoried plant communities and analysed soil physico-chemical properties on 100 plots with various past land uses according the Etat-Major map (arable, pasture or forest) and in situ PLU remnants (terrace, stone removal or no remnants). Compared to ancient forest, former arable land hosted more species and had deeper and nutrient-richer soils while former pasture had shallower and nutrient-poorer soils. Similarly, and compared with no remnants, terraces hosted more species and had deeper and nutrient-richer soils whereas stone removal had shallower and nutrient-poorer soils. Understory species composition significantly varied according to map-based PLU and in situ PLU remnants. However, in situ PLU remnants were globally a much better indicator of land use legacies on soil and understory plant composition compared to map-based PLU. We thus confirmed the legacies of past land use on Mediterranean forest soil and understory vegetation. We also stressed that historical ecology should rely on both field evidence and historical maps, particularly in Mediterranean landscapes with a complex history of land uses.
\end{abstract}

\section{Introduction}

Humans have transformed the land since immemorial times with fire, land clearing for agriculture and landscaping (Kaplan et al., 2009). Even centuries after land use change, former land use can conserve a long lasting impact on ecosystems (Dupouey et al., 2002a; Plue et al., 2008). Historical ecology, "the study of human impacts on ecosystems and landscapes over time" (Bürgi and Gimmi, 2007; Szabó, 2015; Armstrong et al., 2017), has been a subject of growing interest in the past decades, notably concerning forests (Szabó, 2015). Especially,

Abbreviations: AF, ancient forest; EM, Etat-Major; FAO, Food and Agriculture Organization; IS-PLUR, in situ past land use remnants; MB-PLU, map-based past land use; PLU, past land use; PNRL, Regional Natural Park of Luberon; RDA, redundancy analysis; RF, recent forest

* Corresponding author.

E-mail address: juliet.abadie@irstea.fr (J. Abadie). 
historical ecology has highlighted strong legacies of former land use on current forest ecosystems and stressed that taking into account forest history is crucial for species conservation (Vellend et al., 2013).

Two types of forests are usually distinguished according to their temporal continuity: "ancient forests" which already existed before a threshold date and "recent forests" which have developed on former non-forest soils, mostly cropland or pasture, after this threshold date (Peterken and Game, 1984; Goldberg et al., 2007; Hermy and Verheyen, 2007). The concept of forest continuity relies on the temporal continuity of its use as a forest, i.e. forest stands may have been logged but forest soils must have not been cleared for agricultural use. Historical maps are often used to define the threshold date (e.g. Peterken and Game, 1984; Honnay et al., 1998; Dupouey et al., 2002b; Bergès et al., 2016) and describe forest spatial distribution (Vuorela et al., 2002; Kaim et al., 2016). However, the comparison between ancient and current land use can be difficult not only because map accuracy can strongly vary between ancient and current maps (Vuorela et al., 2002; Leyk et al., 2006), but also because land use or land cover definitions can change over time (Vuorela et al., 2002; Bieling et al., 2013). Moreover, a turnover in land cover might occur between two maps: a forest can be considered ancient because recorded in both historical and current maps, but may have been deforested meanwhile. In France, several historical maps exist but the most reliable is the "Etat-Major" (EM) map (Dupouey et al., 2007): it was drawn at the national scale following a standardised protocol and displays a relatively high resolution and precision compared to other ancient national maps (map scale: 1:40,000; median position error ca. $25 \mathrm{~m}$ after geometric correction). This map was drawn from 1818 to 1866, a period which corresponds to the "forest transition", i.e. the turning point from an overall deforestation to a continuous and massive forest recovery (Mather et al., 1999). Consequently, we can reasonably assume that the forest patches mapped on the EM map were probably already long established, and that little deforestation occurred after this date.

In temperate regions, soil and understory vegetation differences have been highlighted between ancient and recent forests (Flinn and Vellend, 2005; Hermy and Verheyen, 2007). Compared to ancient forests, post-agricultural forests have less acidic soils with lower organic matter (due to matter exportation during agricultural use) but higher nutrient content, such as phosphorous (due to nutrient inputs during agricultural use) (e.g. Koerner et al., 1997; Compton and Boone, 2000; Dupouey et al., 2002a). Species more frequent in ancient forests (ancient forest species) have short distance dispersal mechanisms and no persistent soil seed bank (dispersal limitation, Hermy and Verheyen, 2007). Some of them may also be sensitive to change in soil characteristics or competition with ubiquitous species (environmental filtering). Ancient forest species are thus less able to colonise new forests than other forest species, which makes them more vulnerable to forest habitat loss, even temporary, and represent a conservation issue.

Land use legacies on current forest soils, species richness and composition have been much less explored in Mediterranean forests compared to temperate forests (Amici et al., 2013; Kouba et al., 2015; Basnou et al., 2016). Basnou et al. (2016) found that forest continuity had a weak effect on woody species, while Kouba et al. (2015) highlighted a loss in late-successional species in Mediterranean forests due to intensive and widespread previous agricultural use in this region. Amici et al. (2013) showed that light-demanding species richness decreased with increasing successional age of forest, despite the open forest canopy measured in forests at all successional ages. However, those three studies only concerned the last fifty years and did not go further back in time. Here we focused on the history of Mediterranean forests over the last 150 years.

Research on the soil and understory vegetation differences between ancient and recent forest has little investigated the nature of the land use prior to forest recovery. However, past land uses (PLUs) do not equally influence current forest ecosystems. For instance, Koerner et al. (1997) and Dyer (2010) both highlighted that forests developed on former pasture show similar pattern with ancient forests, while former crop or garden have a much stronger legacy effect on soil characteristics and plant species richness. Arable soils are altered by ploughing, topography levelling and nutrient inputs, while pasture soils are altered by trampling (Flinn et al., 2005), and may be impoverished by biomass exportation. Due to intense soil tillage and fertilisation, land use legacies of former culture on current soil and understory vegetation are thus hypothesised to be stronger compared to former pasture (Koerner et al., 1997; Compton and Boone, 2000; Wulf, 2004).

The Mediterranean region is characterised by strong biophysical constraints: water limitations due to hot and dry summers and hard calcareous substrates result in a specific agriculture (vineyards, olive trees, lavender). A rugged topography led farmers to cultivate slopes, resulting in the traditional Mediterranean landscape characterised by terraced crops and extensive grazing. The Mediterranean region is also characterised by a former agro-sylvo-pastoral management of the landscape. Herds of sheep and goats were put out to pasture on crops after harvest to enrich soils but also in forest and garrigue to complete their diet. Forests were temporarily cleared and cultivated ("essartage"), while boxwood (Buxus sempervirens) and litter were used to fertilise crops (Gilbert, 1989; Chalvet, 2006). Potential multiple uses of the land during short periods thus question the relevance of using historical maps in our context. Testimonies of past agricultural use directly detectable in Mediterranean forests are terraces and stone removal remnants, i.e. large piles of stones or stone walls. Terraces testify an ancient established agricultural use whereas stone removal might reveal ancient temporary agricultural use (de Réparaz, 2000) (Appendix A1). Terraces can date back to the Middle Ages, but their largest extension occurred during the eighteenth and nineteenth centuries (Ambroise et al., 1989; Arnaez et al., 2015), so most of cultivated terrace were probably contemporary of the EM map. Stone removal have been practiced for a long time but no information was found about a preferential period of use. In addition, different land uses probably successively occurred on a same plot. Land use legacies on current forest can overlap and three processes may occur: a persistent effect of the last land use before reforestation; a stronger effect of the more impacting land use irrespective of its date and duration (e.g. arable use over pasture); a cumulative effect of the successive former land uses preceding reforestation. In our case, we assumed that if a land use remnant was still visible now, its legacies were persistent and dominant, irrespective of the time since forest recovery and the succession of land use in the past. There was no evidence of former pastoral use in the field, but we hypothesized that pastoral pressure was more intense in pasture identified on the EM map, even though the whole land might have been temporarily grazed in the traditional agro-sylvo-pastoral management system. Thus, the two historical sources might be helpfully combined to better understand the effect of former land use on current soil and vegetation.

Our main objective was to examine the effect of different PLUs on soil physico-chemical properties and understory vegetation of Mediterranean forests and to compare the relevance of two different sources: ancient maps (hereafter map-based PLU) and remnants recorded in the field (hereafter in situ PLU remnants). Our general hypothesis was that in situ PLU remnants better indicate the effect of PLU on soil and vegetation than map-based PLU. Specifically, we asked the following questions: (1) Can we detect long-term PLU effect in Mediterranean forests using ancient maps (map-based PLU), and do different map-based PLU (arable land, pasture or forest) have a contrasting effect on soil and understory vegetation? (2) What is the effect of in situ PLU remnants and what are the legacies of the different in situ PLU remnants on current soil and vegetation? (3) Do map-based PLU and in situ PLU remnants legacies concern the same soil and vegetation components; do they have the same magnitude and direction; and are their effects additive? 


\section{Material and methods}

\subsection{Study area}

The Regional Natural Park of Luberon (PNRL) is located in the eastern French Mediterranean region $\left(43^{\circ} 39^{\prime} \mathrm{N}-44^{\circ} 02^{\prime} \mathrm{N}, 4^{\circ} 58^{\prime} \mathrm{E}-5^{\circ} 55^{\prime} \mathrm{E}\right)$ and covers 195,413 ha. Climate is typically Mediterranean, made up of mild and humid winters and hot and dry summers: annual mean precipitation is around $710 \mathrm{~mm}$ and mean temperature is $13^{\circ} \mathrm{C}$ (Varese, 1990). Lithology is mostly calcareous (95\%). More than half of the area is now covered by forests (55\%), mainly located in hilly zones and mostly composed of holm oak (Quercus ilex - 22\%), downy oak (Quercus pubescens - 23\%) and Aleppo pine (Pinus halepensis - 18\%) stands. The western part, which is more exposed to the cold and dry "Mistral" wind, is drier and more subject to wild fires. Seventy-one percent of the total forest cover is private, and most forest management does not follow any specific silvicultural treatment.

Until mid-nineteenth century, the economy of the region was based on an agro-sylvo-pastoral system. Forests were mostly coppiced for charcoal, firewood and tanning (oak bark). Then, the socioeconomic and political context led to land abandonment and forest gradually recovered on former pasture and arable land from the mid-nineteenth century to the late twentieth century (Fourchy, 1963; Gilbert, 1989; Chalvet, 2006). The PNRL was created in 1977 to reconcile economic development and preserve traditional rural activities.

\subsection{Sampling design}

Present forest cover was extracted from the National Forest map, digitised by the National Forest Inventory (http://inventaire-forestier. ign.fr/spip/spip.php?rubrique53; 1:25,000) using orthophotographs of 2005 (western part) and 2009 (eastern part). Map-based PLU was obtained from the Etat-Major map (1858-1861 in the study area) which was digitised following Favre et al. (2013) (Salvaudon et al., 2012). Half of current forests were ancient (45\%), while recent forests were equally developed on former pasture (49\%) and arable land (48\%). Arable land included annual crops, hay meadows, vineyards and tree crops, which were trees used for fruit or olive production, often planted with annual crops. Pasture corresponded to grazed grasslands and Mediterranean shrubland ("garrigue"). In situ PLU remnants were recorded during field survey (Appendix A1): stone removal remnants included large stone piles and stone walls; terraces were easily noticeable and were most probably former olive tree crops as we found dead olive trees in some plots. Moreover, olive trees were traditionally the main cultivated tree on terrace in the French Mediterranean region (de Réparaz, 2000), but were probably very often planted with annual crops.

We selected fifty pairs of forest patches so that each pair included adjacent ancient and recent forest patches with the same dominant tree species, a relatively closed canopy cover and a homogeneous structure to properly control for site conditions variability. Former pasture and cropland were nearly equally represented in recent forest (Table 1). Sampling design covered the whole study area (Fig. 1) to include the

Table 1

Plot distribution according to map-based past land use and in situ past land use remnants.

\begin{tabular}{lllll}
\hline \multicolumn{4}{c}{ Map-based past land use (1860) } & \\
\cline { 2 - 5 } & Forest & Pasture & Arable & Total \\
\hline In situ past land use remnants & & & \\
Absence & 37 & 21 & 7 & 65 \\
Stone removal & 13 & 4 & 3 & 20 \\
Terrace & 0 & 2 & 13 & 15 \\
Total & 50 & 27 & 23 & 100 \\
\hline
\end{tabular}

three different dominant tree species in the region: $P$. halepensis, $Q$. ilex and $Q$. pubescens. We surveyed one plot within each forest patch (100 plots). To avoid edge effect, each forest patch had a minimum surface of two hectares and plots were located at least $50 \mathrm{~m}$ away from an open habitat edge. Recent forest plots were situated on average at $92 \mathrm{~m}$ from the nearest ancient forest border, while ancient forest plots were situated on average at $77 \mathrm{~m}$ from the nearest recent forest border. The pairing of plots was impossible to set up for in situ PLU remnants due to sampling constraints (adjacent ancient and recent forest patches) and because we also found in situ PLU remnants in ancient forests, contrary to what one might expect (Table 1). However, among the 13 plots with stone removal in ancient forests, nine were adjacent to an ancient crop, which could indicate that stones might have come from the adjacent crop and not from the ancient forest itself. We avoided charcoal kiln sites and places where we found evidence of recent fires. Forest continuity was refined using 1958 aerial photographs and among the 15 plots on terrace, three were still visible in 1958.

\subsection{Floristic and soil survey}

We carried out floristic survey from early May to early July 2015. Plots covered $200 \mathrm{~m}^{2}$ to capture floristic richness and diversity. Within each plot, we recorded the abundance of any vascular plant species measuring less than $2 \mathrm{~m}$ high following the Braun-Blanquet method (Braun-Blanquet, 1964). Plants were identified at species or genus level using the French Mediterranean Flora (Tison et al., 2014) and a local Flora (Girerd and Roux, 2011). The nomenclature followed taxref v.8 (https://inpn.mnhn.fr/telechargement/referentielEspece/ referentielTaxo).

We sampled soil within the floristic survey plot from September to December 2015. We measured soil depth with a pedological auger at three points. After litter removal, the $0-10 \mathrm{~cm}$ topsoil layer was collected at three locations randomly selected within the plot, mixed, air dried and sieved to $2 \mathrm{~mm}$. Soil samples were then analysed for organic carbon and total nitrogen content (following standards ISO-10694 \& ISO-13878), inorganic phosphorous content (Duchaufour and Bonneau, 1959), pH (in water - ISO-10390), active and total limestone (X 31-106 \& ISO 10693), and texture (ISO 11277) by the certified soil laboratory of INRA Arras.

\subsection{Explanatory variables}

Explanatory variables were the two past land use variables: mapbased PLU (forest, pasture and arable) and in situ PLU remnants (absence of noticeable remnant, stone removal and terrace).

Environmental conditions and landscape variables were measured to control for variability within paired plots (ancient forest versus recent forest, Appendix A2) and between the fifty sites. We recorded canopy cover, dominant tree height, tree species richness, tree density and total basal area within a $20 \mathrm{~m}$ radius during field survey. Additionally, we obtained elevation, slope and aspect from a digital elevation model with a resolution of $25 \mathrm{~m}$ (Appendix A3). Aspect was transformed into northness (the cosine of aspect). Current habitat patch area (area of forest with the same dominant tree species) and distance to the closest open habitat edge were also measured on present forest map.

We tested correlations between explanatory variables before analysis (Appendix A3). Map-based PLU and in situ PLU remnants were significantly correlated $(\mathrm{p}<0.0001)$ : we found most terraces on former arable land, while stone removal mostly concerned ancient forests and in most cases, we detected no terrace or stone pile on former pasture (Table 1).

\subsection{Data analysis}

For each plot, species cover coefficients were transformed into mean cover values following Gounod (1969). Then we calculated three plant 


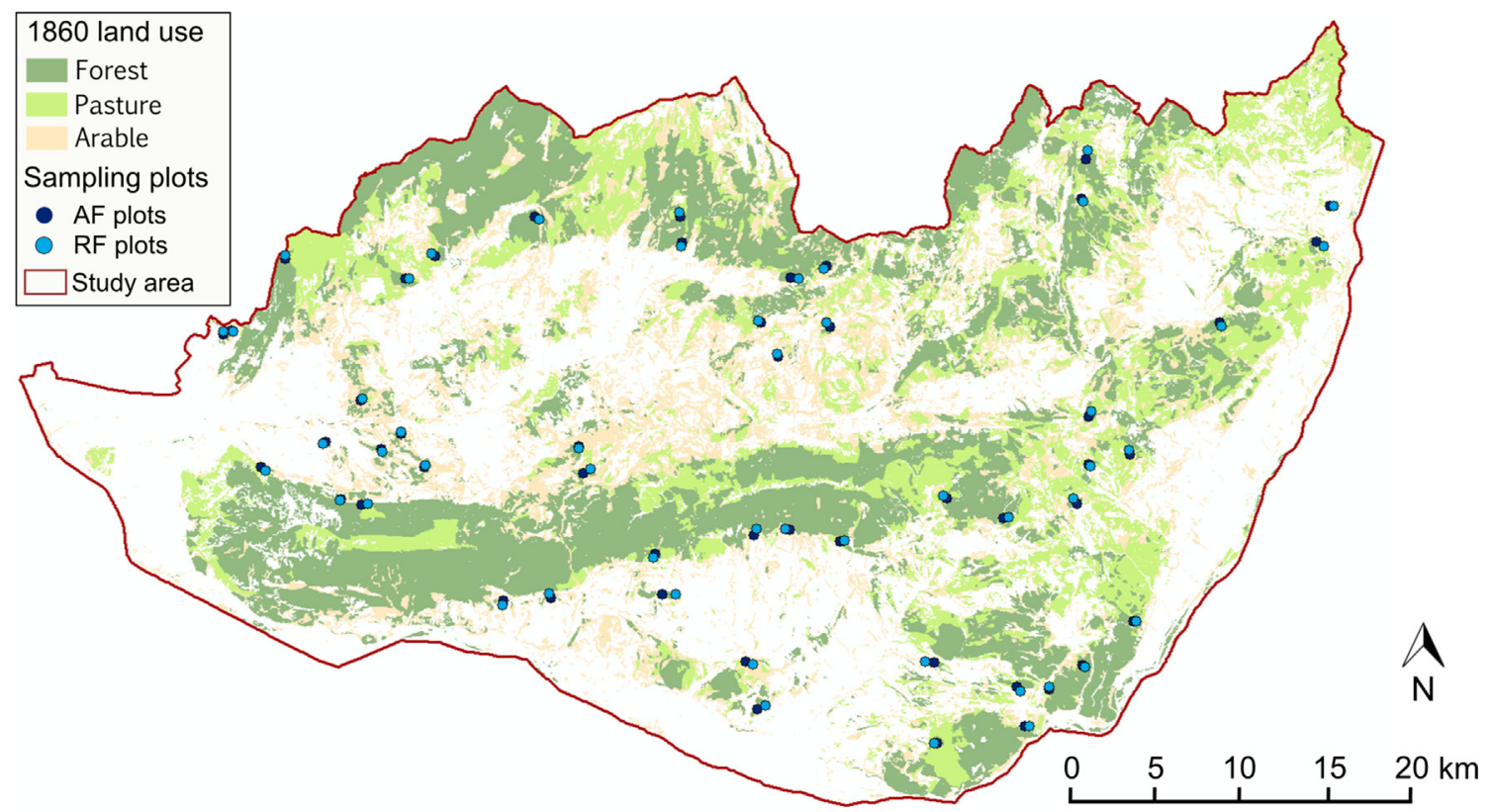

Fig. 1. 1860 land use of current forests and survey plot distribution in the study area. AF = ancient forest; RF = recent forest.

Table 2

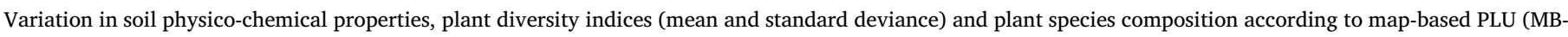

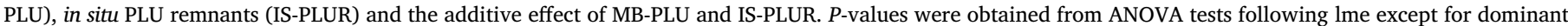
tree species for which they were obtained from Chi-square test. Significant $p$-values are given in bold; $0.05>*>0.001>* *>0.0001>* * *$.

\begin{tabular}{|c|c|c|c|c|c|c|c|c|c|c|}
\hline & \multicolumn{4}{|l|}{ MB-PLU } & \multicolumn{4}{|l|}{ IS-PLUR } & \multicolumn{2}{|c|}{ MB-PLU + IS-PLUR } \\
\hline & Forest & Pasture & Arable land & $p$-value & Absence & Stone removal & Terrace & $p$-value & $\begin{array}{l}\text { MB-PLU } \\
p \text {-value }\end{array}$ & $\begin{array}{l}\text { IS-PLUR } \\
p \text {-value }\end{array}$ \\
\hline Number of plots & 50 & 27 & 23 & - & 65 & 20 & 15 & - & - & - \\
\hline Slope (\%) & $12.7 \pm 6.9$ & $12.5 \pm 6.9$ & $10.3 \pm 5.1$ & $0.02^{*}$ & $14.0 \pm 6.4$ & $6.3 \pm 4.3$ & $11.6 \pm 5.0$ & $0.001^{\text {**t }}$ & $0.09 \mathrm{~ns}$ & $0.006^{\text {** }}$ \\
\hline Canopy cover (\%) & $41.9 \pm 19.5$ & $42.8 \pm 17.4$ & $43.5 \pm 19.7$ & $0.8 \mathrm{~ns}$ & $38.6 \pm 20.1$ & $53.0 \pm 11.7$ & $45.3 \pm 15.5$ & $0.008^{\text {*k }}$ & $0.8 \mathrm{~ns}$ & $0.009^{\text {** }}$ \\
\hline Dominant tree species & - & - & - & $1 \mathrm{~ns}$ & P. hal \& Q. ilex & Q. ilex \& Q. pub & Q. pub & $0.003^{* *}$ & - & - \\
\hline $\mathrm{C}$ org $\left(\mathrm{g} \mathrm{kg}^{-1}\right)$ & $44.5 \pm 23.2$ & $45.1 \pm 25.8$ & $38.8 \pm 24.9$ & $0.1 \mathrm{~ns}$ & $44.6 \pm 23.1$ & $50.3 \pm 31.3$ & $28.7 \pm 9.4$ & $0.003^{* * t}$ & $0.6 \mathrm{~ns}$ & $0.02^{*}$ \\
\hline $\mathrm{C} / \mathrm{N}$ & $17.6 \pm 2.4$ & $17.5 \pm 2.2$ & $17.5 \pm 3.5$ & $0.9 \mathrm{~ns}$ & $18.2 \pm 2.8$ & $16.7 \pm 1.7$ & $15.9 \pm 1.7$ & $0.01^{*}$ & $0.3 \mathrm{~ns}$ & $0.003^{k *}$ \\
\hline $\mathrm{pH}$ & $7.9 \pm 0.4$ & $7.8 \pm 0.5$ & $8.1 \pm 0.2$ & $0.01^{*}$ & $7.9 \pm 0.4$ & $7.8 \pm 0.3$ & $8.2 \pm 0.2$ & $0.02^{*}$ & $0.3 \mathrm{~ns}$ & $0.3 \mathrm{~ns}$ \\
\hline $\mathrm{P}$ acid $\left(\mathrm{g} \mathrm{kg}^{-1}\right)$ & $0.008 \pm 0.02$ & $0.006 \pm 0.02$ & $0.005 \pm 0.008$ & $0.6 \mathrm{~ns}$ & $0.004 \pm 0.01$ & $0.02 \pm 0.03$ & $0.005 \pm 0.007$ & $0.1 \mathrm{~ns}$ & $0.7 \mathrm{~ns}$ & $0.1 \mathrm{~ns}$ \\
\hline P basic $\left(\mathrm{g} \mathrm{kg}^{-1}\right)$ & $0.04 \pm 0.04$ & $0.04 \pm 0.05$ & $0.04 \pm 0.06$ & $0.7 \mathrm{~ns}$ & $0.03 \pm 0.03$ & $0.07 \pm 0.07$ & $0.03 \pm 0.06$ & $0.8 \mathrm{~ns}$ & $0.7 \mathrm{~ns}$ & $0.8 \mathrm{~ns}$ \\
\hline $\begin{array}{l}\text { Active limestone ( } \mathrm{g} \\
\quad 100 \mathrm{~g}^{-1} \text { ) }\end{array}$ & $3.8 \pm 5.4$ & $3.6 \pm 6.5$ & $5.2 \pm 4.3$ & $0.2 \mathrm{~ns}$ & $4.3 \pm 6.1$ & $1.9 \pm 2.3$ & $5.8 \pm 4.9$ & $0.2 \mathrm{~ns}$ & $0.8 \mathrm{~ns}$ & $0.7 \mathrm{~ns}$ \\
\hline Sand $\left({\left.\mathrm{g} 100 \mathrm{~g}^{-1}\right)}^{-1}\right.$ & $31.0 \pm 18.5$ & $22.8 \pm 14.9$ & $35.4 \pm 18.4$ & $0.2 \mathrm{~ns}$ & $28.2 \pm 17.2$ & $29.9 \pm 20.6$ & $36.5 \pm 17.3$ & $0.8 \mathrm{~ns}$ & $0.2 \mathrm{~ns}$ & $0.8 \mathrm{~ns}$ \\
\hline Coarse fragment (\%) & $42.0 \pm 22.2$ & $44.5 \pm 26.6$ & $36.7 \pm 25.5$ & $0.3 \mathrm{~ns}$ & $43.5 \pm 23.7$ & $46.8 \pm 25.8$ & $25.6 \pm 17.9$ & $0.02^{*}$ & $0.4 \mathrm{~ns}$ & $0.03^{*}$ \\
\hline Soil depth (cm) & $30.5 \pm 16.7$ & $28.6 \pm 15.6$ & $41.6 \pm 22.9$ & $0.001^{* * *}$ & $31.2 \pm 17.4$ & $22.2 \pm 5.1$ & $52.0 \pm 21.1$ & $<0.0001^{* * * *}$ & $0.3 \mathrm{~ns}$ & $<0.0001^{* * * *}$ \\
\hline Humus depth $(\mathrm{cm})$ & $4.1 \pm 2.0$ & $4.1 \pm 2.1$ & $4.0 \pm 1.4$ & $1 \mathrm{~ns}$ & $4.1 \pm 2.1$ & $3.9 \pm 1.5$ & $3.8 \pm 1.6$ & $0.8 \mathrm{~ns}$ & $1 \mathrm{~ns}$ & $0.8 \mathrm{~ns}$ \\
\hline S & $39.4 \pm 12.9$ & $42.7 \pm 12.9$ & $44.6 \pm 15.4$ & $0.03^{*}$ & $38.3 \pm 12.6$ & $45.5 \pm 11.3$ & $49.8 \pm 15.8$ & $0.007^{\text {*kx }}$ & $0.5 \mathrm{~ns}$ & $0.1 \mathrm{~ns}$ \\
\hline Simpson & $0.78 \pm 0.1$ & $0.81 \pm 0.1$ & $0.82 \pm 0.1$ & $0.2 \mathrm{~ns}$ & $0.79 \pm 0.1$ & $0.82 \pm 0.1$ & $0.83 \pm 0.1$ & $0.4 \mathrm{~ns}$ & $0.4 \mathrm{~ns}$ & $0.8 \mathrm{~ns}$ \\
\hline $\mathrm{J}$ & $0.65 \pm 0.1$ & $0.67 \pm 0.1$ & $0.68 \pm 0.1$ & $0.4 \mathrm{~ns}$ & $0.65 \pm 0.1$ & $0.68 \pm 0.1$ & $0.68 \pm 0.1$ & $0.6 \mathrm{~ns}$ & $0.6 \mathrm{~ns}$ & $0.9 \mathrm{~ns}$ \\
\hline RDA analysis & - & - & - & $0.04^{*}$ & - & - & - & $<0.001^{k \text { w.tk }}$ & $0.02^{*}$ & $<0.001^{\text {k***k}}$ \\
\hline
\end{tabular}

community indices using the R package vegan (Oksanen et al., 2017): species richness (S), Simpson's diversity index (simp) and equitability index $(\mathrm{J})$. We applied a linear mixed-effect model to test the effect of map-based PLU and in situ PLU remnants on soil physico-chemical properties and plant diversity indices using pair identity as a random effect with the R package nlme (Pinheiro et al., 2017). The effect of map-based PLU and in situ PLU remnants on plant composition was tested by a redundancy analysis (RDA) (Legendre and Legendre, 1998) after removing species present in less than five plots (ter Braak, 1986). We tested the significance of the effect with a permutation test using 999 permutations. For each analysis, we tested the effect of map-based PLU, the effect of in situ PLU remnants and then the additive effect of the two historical variables. We did not test their interaction because of the high correlation between the two variables.

We also tested if PLU was linked to environmental condition differences. First, we independently tested the effect of each environmental variable on each dependant variable (soil physico-chemical properties, plant diversity indices and composition) with a univariate model. Then we performed a multivariate model using all the significant site variables. If two significant variables were correlated ( $\mathrm{R}>0.6$ ), only the most significant was selected and the other was dropped. Those multivariate models were used to test whether the effect of map-based PLU and in situ PLU remnants remained after controlling for environmental conditions (see Appendix A4 for further detail).

The preference of understory plant species for each PLU (map-based 


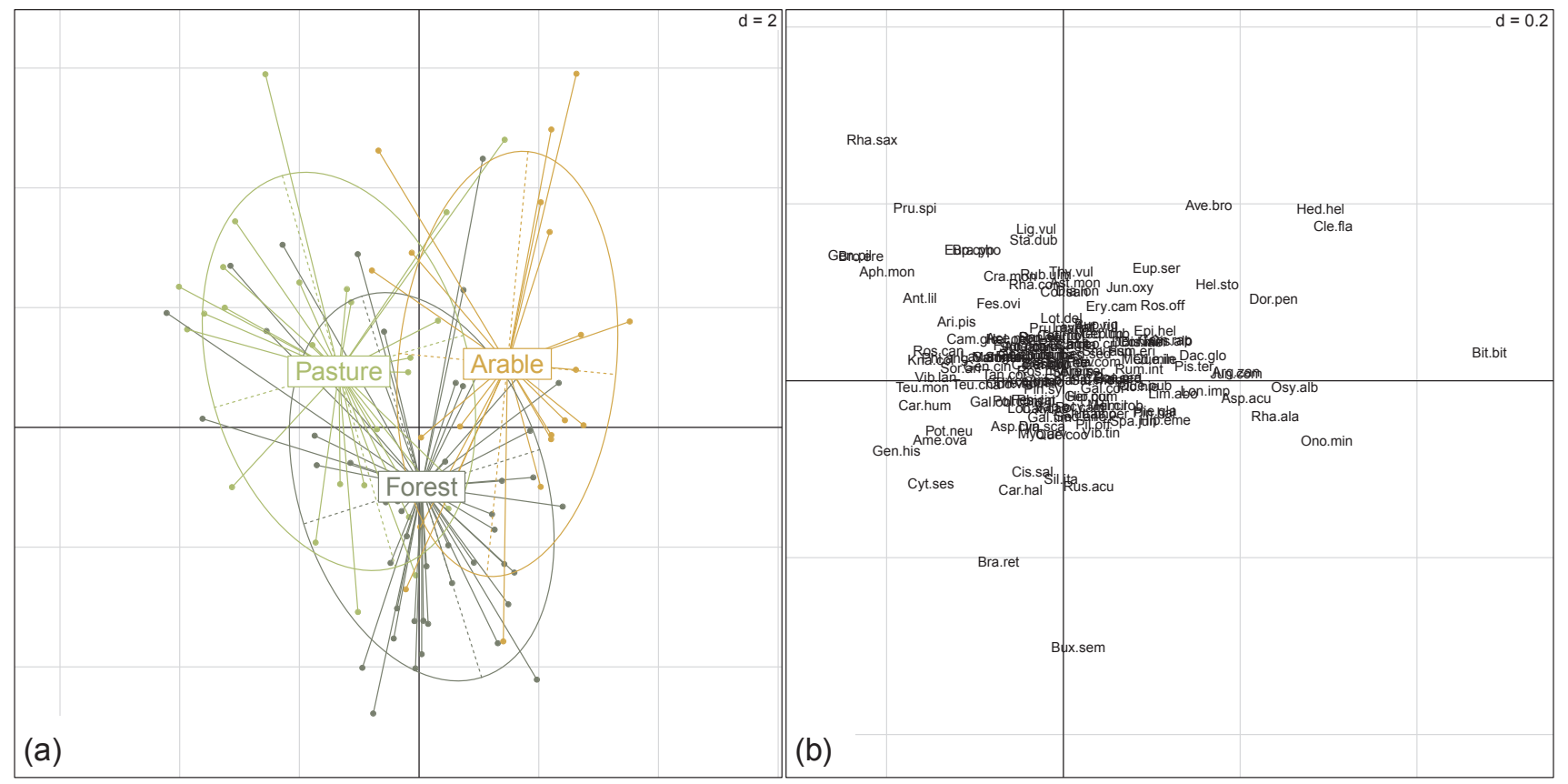

Fig. 2. First RDA factorial map of vegetation communities according to map-based PLU. The RDA was conducted with the abundance of species present in more than five survey plots and is constrained by map-based PLU. (a) Survey plots (vegetation communities) and map-based PLU categories. (b) Species.

or in situ remnant) was determined using the Indicator Value approach (Dufrêne and Legendre, 1997) by a permutation test with the function multipatt of the R package indicspecies (De Cáceres et al., 2010).

Maps were processed using ArcGIS 10.3; statistical analyses were carried out using R software v. 3.2.5 (R Development Core Team, 2017).

\section{Results}

\subsection{Stand characteristics}

Slope significantly varied according to map-based PLU and in situ PLU remnants: slope was slightly higher in ancient forest and former pasture than on former arable land; plots with no PLU remnants displayed the steepest slopes, while plots with stone removal were the flattest (Table 2). When the two historical variables were tested together, slope only responded significantly to in situ PLU remnants (Table 2). Canopy cover and dominant tree species significantly varied according to in situ PLU remnants: plots on stone removal were the most shaded while plots with no PLU remnants were the least shaded; terrace plots were mostly represented in Quercus pubescens stands. The relationships between PLU factors and the other stand characteristics are presented in Appendix A4.

\subsection{Soil physico-chemical properties}

The soils sampled were mostly calcareous and neutral to alkaline (pH range 6.2-8.5, mean 7.9), and texture was dominantly clay-loam.

Map-based PLU had a significant effect on $\mathrm{pH}$ and soil depth: former arable land had higher $\mathrm{pH}$ and deeper soils while former pastures had lower $\mathrm{pH}$ and shallower soils than ancient forests (Table 2). In situ PLU remnants had a significant effect on organic $\mathrm{C}$ content, $\mathrm{C}: \mathrm{N}$ ratio, $\mathrm{pH}$, coarse fragment content and soil depth. Terraces had lower organic carbon content and C:N ratio, higher $\mathrm{pH}$ and deeper soils with a lower coarse fragment content. Except for C:N ratio, plots with no PLU remnants showed intermediate values between terrace and stone removal. Moreover, map-based PLU effect was no longer significant for any soil variable after controlling for in situ PLU remnant effect (Table 2). $\mathrm{pH}$ significantly varied with both historical variables in the unifactorial models.

\subsection{Plant communities}

In the 100 plots, we recorded 363 taxa, 323 being identified at the species level (Appendix A5). The most frequent species were Rubia peregrina, Quercus pubescens, Quercus ilex, Carex halleriana, Hieracium glaucinum, Lonicera etrusca, Aphyllanthes monspeliensis, Festuca ovina and Thymus vulgaris. There was no significant difference in species richness between former pastures and ancient forests $(p=0.2)$ while former arable land had on average 5.2 species more than ancient forests $(p=0.02)$. Former arable land was on average 1.9 species richer than former pastures, but the difference was not significant $(p=0.3)$. Species richness also varied according to in situ PLU remnants: terraces were on average 11.5 species richer than no remnants ( $p=0.003)$, but there was no significant difference in species richness between no remnant and stone removal $(p=0.2)$ and between terrace and stone removal remnants $(p=0.1)$. Diversity and equitability indices (simp and J) did not vary with historical factors. While in situ PLU remnants had a stronger effect on species richness in the unifactorial models compared to map-based PLU, neither of the two historical variables was significant in the additive bifactorial model (Table 2).

Understory species composition significantly varied according to map-based PLU and in situ PLU remnants in both the unifactorial and additive bifactorial models, but the effect of in situ PLU remnants was much stronger (Table 2). The lower effect of map-based PLU on plant composition is revealed by the overlap of the three PLU classes on the first RDA factorial map (Fig. 2a). Concerning in situ PLU remnants, the first axis distinguished absence from the presence of in situ PLU remnants, while the second axis separated stone removal from terrace (Fig. 3a).

Indicator value analysis indicated that seven species were associated to one or two map-based PLU (Fig. 2b, Appendix A6): Anthyllis vulneraria was significantly more frequent in former pastures, Bituminaria bituminosa, Dactylis glomerata and Helichrysum stoechas in former arable land, Rhamnus saxatilis and Ligustrum vulgare in former pasture or arable land and Potentilla neumanniana in former pasture and ancient forest. No species was associated with ancient forest only. Concerning in situ PLU remnants, Lactuca perennis, Polypodium cambricum and Genista 


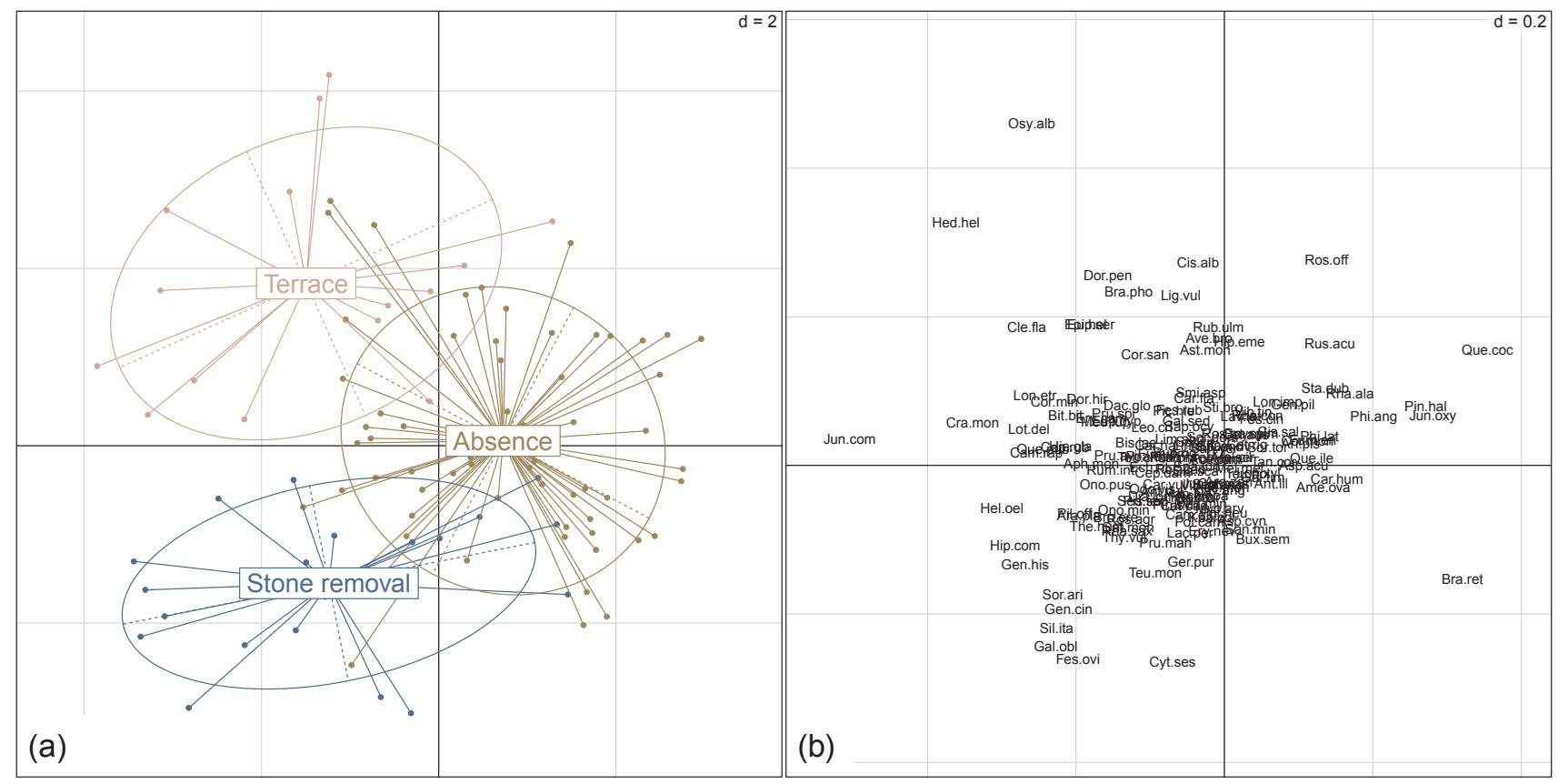

Fig. 3. First RDA factorial map of vegetation communities according to in situ PLU remnants. The RDA was conducted with the abundance of species present in more than five survey plots and was constrained by in situ PLU remnants. (a) Survey plots (vegetation communities) and in situ PLU remnants categories. (b) Species.

cinerea were significantly more frequent on stone removal, while Osyris alba, Epipactis helleborine, Euphorbia serrata, Ligustrum vulgare, Cistus albidus, Astragalus monspessulanus and Smilax aspera were significantly more frequent on terrace. Moreover, 26 species indicated either terrace or stone removal. No species characterised the lack of in situ PLU remnants (Fig. 3b, Appendix A6).

\section{Discussion}

\subsection{Stronger legacies of in situ PLU remnants than map-based PLU}

\subsubsection{Soil physico-chemical properties}

Land use legacies on current forest soils and understory plant communities as indicated by the EM map were not highly significant, but some legacies were clearly noticeable. First, we highlighted that former arable land had deeper soil (thus a probably higher water availability) and higher $\mathrm{pH}$ compared to former pasture and ancient forest. This trend can result from: (1) pre-existing differences in biophysical conditions between lands that were cropped, grazed or remained as forest in the period before the EM map; (2) legacies of former land use (arable land, pasture or forest) on soil properties (Flinn et al., 2005; Wulf et al., 2010). (1) We have shown in Abadie et al. (2018) that arable land was more frequently established on soils with higher potential productivity, notably with higher water content. On the contrary, sheep and goats herds were principally put out to pasture on land with low productivity (Taillefumier and Piegay, 2003). (2) Traditional land management systems can result in mineral transfers $(\mathrm{N}, \mathrm{P})$ from pasture and forest to cropland, through animal manure and forest litter removal, thus modifying soil nutrient content, biogeochemical fluxes and consequently $\mathrm{pH}$. We can also assume that farmers deepened soils to enhance productivity, through stone removal or terrace development. To properly identify which of these two causes is responsible of the differences we presently observe between ancient and recent forests is not an easy task (Sciama et al., 2009), but we can assume that soil properties were at least partly determined by forest history.

The differences in soil $\mathrm{pH}$ between former arable land, pasture and forest were globally consistent with the results obtained in temperate regions, although lower in magnitude (Koerner et al., 1997; Dupouey et al., 2002a; Flinn et al., 2005; Falkengren-Grerup et al., 2006; Brunet et al., 2011). The calcareous nature of most of the PNRL soils can explain this lower magnitude. Soil base cations availability is not a strong limiting factor of vegetation growth in this region. In contrast, acidic soils were reported to be more frequent in ancient forests compared to recent forests in temperate lowland regions where nutrient-poor soils are frequent (Bergès et al., 2016).

Compared to map-based PLU, in situ PLU remnants had a stronger effect and influenced a higher number of soil characteristics (5 against 2 , see Table 2). Soils on ancient terraces were the most productive (the deepest, highest in $\mathrm{pH}$ and lowest in coarse fragments content), while soils on stone removal were the least productive. As terraces testify a former agricultural use, our study confirms previous results found in temperate regions: soils of forests developed on former arable land contain less organic matter (Koerner et al., 1997; Compton and Boone, 2000; Dupouey et al., 2002a; Valtinat et al., 2008; Brudvig et al., 2013). In contradiction with previous studies (Hermy and Verheyen, 2007), phosphorous content was not higher in former arable land. The very low available phosphorous content of our soils may be due to the fact that they were subject to repeated fires (Duguy et al., 2007), or that we sampled plots that were not intensively fertilised. In our context, the legacies of terrace crops may depend more on the enhancement of soil fertility by soil levelling and deepening than by fertiliser inputs. Surprisingly, stone removal remnants, supposedly remnants of a former agriculture, potentially lower in intensity, displayed opposite effects on soil physico-chemical properties.

\subsubsection{Plant communities}

Recent forests developed on former arable land, especially terrace, hosted more species than ancient forests. These results are consistent with previous observations in temperate regions (Koerner et al., 1997; Compton and Boone, 2000; Wulf, 2004), even if the difference in total plant species richness between recent and ancient forests is not the rule (Brudvig et al., 2013; Matuszkiewicz et al., 2013). The higher species richness we detected in recent forests could result from (1) the succession process, which involves an overlap of species assemblages of different forest successional stages in recent forests, as demonstrated in Mediterranean forests by Amici et al. (2013) and (2) the positive 
relationship between soil fertility and species richness, soils on former terrace being the deepest, and thus the most fertile (Grime, 1973; Aarssen, 2001).

Understory plant species richness and composition slightly varied among map-based PLUs, in accordance with previous results conducted in temperate forests (Hermy and Verheyen, 2007; Dyer, 2010; Brudvig et al., 2013; Bergès et al., 2017). However, the magnitude of the effect was rather low. First, the weak plant composition difference we observed may be due to the relatively high forest cover in 1860 (27\%), the good maintenance of ancient forests in the present forest cover (41\%) and the suitable connectivity of recent forest patches to ancient forest patches (the distance between the recent forest plots and the closest ancient forest edge was only $92 \mathrm{~m}$ in our sample). In the mountainous context of the French Alps, Janssen et al. (2018) did not detect a significant difference in understory plant composition between recent and ancient forests and attributed this lack of PLU effect to a forest landscape history that is similar to ours (high amount of ancient forest, low level of forest fragmentation, and widespread forest recovery). This landscape context could imply that many forest species present in ancient forest patches may have already colonised newly established recent patches and colonisation credit has been partly paid off (Jackson and Sax, 2010). Second, the temporal use of forests for agriculture (temporal use as crop or stock grazing) which was common in former agro-sylvo-pastoral systems (Fourchy, 1963; Gilbert, 1989; Chalvet, 2006) may have smoothed the legacies of PLUs. For example, ancient forests in our study area according to the EM map might have been temporarily cultivated or grazed, while ancient forests in temperate regions may have been submitted to fewer disturbances apart from intensive exploitation (Hardy, 2017).

In contrast, understory plant species richness and composition strongly varied according to in situ PLU remnants: the greatest compositional difference was between the class 'no remnant' and the two other classes; stone removal and terrace also showed significant but less pronounced differences. The difference in species composition was mainly due to species added to the community in plots with terrace and stone piles. The species preferentially found in plots with terrace or stone removal grew there when the land was cultivated, and remained after agricultural set-aside and reforestation: they are probably prone to disappear in the long-term according to the successional process (Jackson and Sax, 2010). Two hypotheses could explain the lack of indicator species for 'no remnants': (1) species found in ancient forest already colonised new forest patches; (2) ancient forest species had already disappeared because of the very long duration of the agrosylvo-pastoral system (as long as we consider that no remnant meant true ancient forest) which would explain why other species easily colonised new forest patches due to their dispersal capacity (Hermy and Verheyen, 2007). Testing these hypotheses requires further investigation on a larger dataset and with a higher temporal resolution, allowing a better understanding of forest succession.

We thus detected legacies of PLU on soil and vegetation in adjacent ancient and recent forest patches. Therefore, we can assume that species distribution according to PLU is not only determined by dispersal limitations but also by recruitment limitations, as pointed out by Amici et al. (2013).

\subsubsection{Consistent but globally no additive effect of map-based PLU and in situ PLU remnants}

The effect of terrace remnants on soil and vegetation was consistent with the effect of map-based former arable land: they displayed the same trend for most of the soil physico-chemical properties and for species richness, and showed the strongest difference with the two other PLU categories. This result was not surprising since half of the plots on former arable land were on terraces. However, the effect of in situ PLU remnants was much higher than that of map-based PLU, which indicates that former terraced crops had the strongest impacts on soil and vegetation. Our results show that the rearrangement of soils following terrace establishment produced very significant land use legacies.

Our results did not support our initial hypothesis of a temporary agricultural use in areas with stone removal: these ecological legacies were different from those detected on terrace but close to those observed on former pasture. Interestingly, former pasture and stone removal shared the same effect on soil and plant species richness: highest coarse fragment and organic carbon content, lowest $\mathrm{pH}$, shallowest soils and intermediate species richness. Two hypotheses could be proposed to explain this unexpected result. First, we cannot formally exclude that stone removal might be related to former pastoral use at least in some circumstances. We could further assume that small stone piles could be related to pastoral use whereas large stone piles could be linked to agricultural use. Nevertheless, we did not find archives or documents to support this hypothesis in our study area. Second, we can hypothesise that these areas with stone piles were actually used to store stones removed from an adjacent arable field, as indicated by the fact that most of our plots with stone removal were adjacent to an ancient crop (nine over thirteen). These sites could have been selected to store the stones precisely because of less suitable biophysical conditions for agriculture. In that case, the soil fertility of the surveyed plot would certainly not have been modified by stone removal. As a result, our two hypotheses could explain the ecological similarity between plots with stone piles and former pasture: plots with stone piles testified to harsh biophysical conditions, while former pasture mostly occurred on the least productive land. Therefore, a more in-depth analysis of the size, shape and spatial configuration of the stone piles and of their surrounding landscape is required to elucidate where the stone piles came from and their agricultural or pastoral role, and would help to clarify their ecological legacies.

Given the long history of agriculture in the Mediterranean area, any part of the territory might have been used for cultivation during a more or less long period. Then areas with no PLU remnants might have been used for cultivation anyway, and the lack of PLU remnants would only reflect the pre-existing adequate intrinsic fertility of the area for cultivation purposes, so that no land management was required. If forests with stone removal remnants were previously used for cultivation, the fertility gradient "terrace-absence-stone removal" would simply reflect the fact that even after stone removal, they remained the least productive areas.

Finally, we detected no additive effect of map-based PLU and in situ PLU remnants, and most of the significant effects of map-based PLU became not significant after statistically controlling for in situ PLU remnant influence (except for species composition). Thus, the effect of map-based PLU could actually be a hidden effect of in situ PLU remnants, as the two historical factors were not independent.

\subsection{Is the Etat-Major map relevant in a Mediterranean context?}

Our study stressed the importance of not relying only on historical maps. In some studies, in situ PLU remnants were also recorded to confirm the accuracy of the historical map used (e.g. Peterken and Game, 1984), but thanks to the recent availability of large scale historical maps (Kaim et al., 2016), more and more studies are carried out without field survey (Kouba et al., 2015; Bergès et al., 2016). Here we underline the limitations of using historical maps, especially in our Mediterranean context.

First, unlike an old photograph, a map is an interpretation of the landscape and we cannot check what the landscape looked like.

Second, semantic differences exist between the interpretation of past and current landscapes. The present forest cover map follows the current FAO definition of forest cover, i.e. a patch with at least $10 \%$ of tree cover and a minimal area of 0.5 ha is considered as a forest (MacDicken, 2012). On the EM map however, the main recognised criterion used to classify land into forest was its main economic use, and fuzzy limits probably exist between land uses, particularly between 
forest and pasture (Bieling et al., 2013). Furthermore, Mediterranean forests display a very heterogeneous physiognomy with open and closed-canopy forests equally represented. Thus, an open forest might have been classified as pasture in 1860 due to its temporary pastoral use. Conversely, we cannot exclude that some forests in 1860 have been mapped as forest but used as pasture, thus blurring the effect of former pasture on soil and vegetation in recent forests. This was especially likely to occur in private forests. Even with a precise archival research, this information would remain hard to obtain. However, we can assume that pastoral pressure on land was stronger in areas mapped as pasture on the EM map than in pastured forest.

Third, as the study area (and the Mediterranean region in general) was characterised by an ancient agro-sylvo-pastoral system, forests might have been temporarily cultivated ("essartage") or grazed (Gilbert, 1989; Chalvet, 2006). This succession of diverse, temporary land uses on a same place cannot be detected on a global map and only land use remnants can testify the succession of different PLUs until today, or at least the last strongly impacting land use before forest recovery, such as terraces. However, we found no in situ PLU remnants reflecting a former pastoral use, and the EM map was the only tool we could rely on to assert past grazing pressure.

A limitation of our study is the lack of precise dating of in situ PLU remnants. Terraces and stone removal development were the highest during the eighteenth and the nineteenth century (Ambroise et al., 1989), during the peak of demographic pressure (Abadie et al., 2018), but in some areas these traditional practices might have been maintained until recently. Terraces still visible today may indicate an agricultural use after 1860. Conversely, terraces that are more ancient may have been missed because remnants have been smoothed by time and soil erosion. However, the terraces we recorded showed very different morphologies and despite some were very well preserved, other displayed a smooth relief and were not easily detectable (Appendix A1). Therefore, we could assume that the time since agricultural abandonment varied among plots with terraces. As the effect of former terrace management was consistent between plots on terraces, we can conclude that former terraces have an effect on forest soil and vegetation, whatever the time since abandonment and the duration of this former use. Further investigation on the recent history of these forests would help to better disentangle the effect of time since abandonment from that of the magnitude of the disturbance on soils and vegetation.

\section{Conclusions and implications for restoration}

Our study confirmed the long-term land use legacies on forest soil and understory vegetation in a Mediterranean context. Soils and vegetation significantly responded to map-based PLU, but the signal of in situ PLU remnants was much stronger. Former terrace and stone removal management displayed diverging effects on soil and vegetation composition, partly due to intrinsic soil fertility: deep, nutrient-rich soils on terrace and shallow, nutrient-poor soils on plots with stone removal remnants. Former pastoral use could not be identified by any in situ PLU remnants and this information was only available on the EtatMajor map. Overall, we stressed the importance of crossing complementary historical materials to fully analyse land use legacies on current forest ecosystems: historical ecology should rely on both field evidence and ancient maps, especially in a Mediterranean context characterised by a traditional agro-sylvo-pastoral system.

The effect of past land use can last for centuries and might be irreversible (Dupouey et al., 2002a; Dambrine et al., 2007; Plue et al., 2008). It is therefore crucial to conserve remaining ancient forests before restoring them with afforestation. Vegetation communities of recent forest tend to resemble vegetation communities of ancient forest with time, but they cannot be the same. It depends on time since abandonment, landscape configuration, local conditions and effect magnitude of past land use.

\section{Acknowledgments}

The authors would like to thank the technical team for its support during field work, without whom this work could not have been achieved. We also thank Aline Salvaudon for providing the cartographical material and Laurent Michel for helping with plant species identification. This work was part of a PhD thesis supported by the Région Provence-Alpes-Côte-d'Azur and IRSTEA.

\section{Declarations of interests}

None.

Appendix A. Supplementary material

\section{References}

Aarssen, L.W., 2001. On correlations and causations between productivity and species richness in vegetation: predictions from habitat attributes. Basic Appl. Ecol. 2, 105-114.

Abadie, J., Dupouey, J.L., Avon, C., Rochel, X., Tatoni, T., Bergès, L., 2018. Forest recovery since 1860 in a Mediterranean region: drivers and implications for land use and land cover spatial distribution. Landsc. Ecol. 33, 289-305.

Ambroise, R., Frapa, P., Giorgis, S., 1989. Paysages de terrasses. Edisud, Aix-en-Provence.

Amici, V., Santi, E., Filibeck, G., Diekmann, M., Geri, F., Landi, S., Scoppola, A., Chiarucci, A., 2013. Influence of secondary forest succession on plant diversity patterns in a Mediterranean landscape. J. Biogeogr. 40, 2335-2347.

Armstrong, C.G., Shoemaker, A.C., McKechnie, I., Ekblom, A., Szabo, P., Lane, P.J., McAlvay, A.C., Boles, O.J., Walshaw, S., Petek, N., Gibbons, K.S., Morales, E.Q., Anderson, E.N., Ibragimow, A., Podruczny, G., Vamosi, J.C., Marks-Block, T., LeCompte, J.K., Awasis, S., Nabess, C., Sinclair, P., Crumley, C.L., 2017. Anthropological contributions to historical ecology: 50 questions, infinite prospects. Plos One 12.

Arnaez, J., Lana-Renault, N., Lasanta, T., Ruiz-Flano, P., Castroviejo, J., 2015. Effects of farming terraces on hydrological and geomorphological processes. A review. Catena $128,122-134$.

Basnou, C., Vicente, P., Espelta, J.M., Pino, J., 2016. Of niche differentiation, dispersal ability and historical legacies: what drives woody community assembly in recent Mediterranean forests? Oikos 125, 107-116.

Bergès, L., Avon, C., Arnaudet, L., Archaux, F., Chauchard, S., Dupouey, J.L., 2016. Past landscape explains forest periphery-to-core gradient of understorey plant communities in a reforestation context. Divers. Distrib. 22, 3-16.

Bergès, L., Feiss, T., Avon, C., Martin, H., Rochel, X., Dauffy-Richard, E., Cordonnier, T., Dupouey, J.-L., 2017. Response of understorey plant communities and traits to past land use and coniferous plantation. Appl. Veg. Sci. 20, 468-481.

Bieling, C., Plieninger, T., Schaich, H., 2013. Patterns and causes of land change: Empirical results and conceptual considerations derived from a case study in the Swabian Alb, Germany. Land Use Policy 35, 192-203.

Braun-Blanquet, J., 1964. Pflanzensoziologie. Grundzüge der vegetationskunde. Springer, Wien - New York.

Brudvig, L.A., Grman, E., Habeck, C.W., Orrock, J.L., Ledvina, J.A., 2013. Strong legacy of agricultural land use on soils and understory plant communities in longleaf pine woodlands. For. Ecol. Manage. 310, 944-955.

Brunet, J., Valtinat, K., Mayr, M.L., Felton, A., Lindbladh, M., Bruun, H.H., 2011. Understory succession in post-agricultural oak forests: Habitat fragmentation affects forest specialists and generalists differently. For. Ecol. Manage. 262, 1863-1871.

Bürgi, M., Gimmi, U., 2007. Three objectives of historical ecology: the case of litter collecting in Central European forests. Landsc. Ecol. 22, 77-87.

Chalvet, M., 2006. Paysages et conflits en Provence. Rives nord-méditerranéennes 23, 11-26.

Compton, J.E., Boone, R.D., 2000. Long-term impacts of agriculture on soil carbon and nitrogen in New England forests. Ecology 81, 2314-2330.

Dambrine, E., Dupouey, J.L., Laut, L., Humbert, L., Thinon, M., Beaufils, T., Richard, H., 2007. Present forest biodiversity patterns in France related to former Roman agriculture. Ecology 88, 1430-1439.

De Cáceres, M., Legendre, P., Moretti, M., 2010. Improving indicator species analysis by combining groups of sites. Oikos 119, 1674-1684.

de Réparaz, A., 2000. Les campagnes de l'ancienne Haute-Provence vues par les géographes du passé, 1880-1950. Les Alpes de Lumière, Mane.

Duchaufour, P., Bonneau, M., 1959. A new method to quantify the available phosphorus of forest soils. Bull. Assoc. Française d'Etude Sol 4, 193-198 (in French).

Dufrêne, M., Legendre, P., 1997. Species assemblages and indicator species: the need for a flexible asymmetrical approach. Ecol. Monogr. 67, 345-366.

Duguy, B., Rovira, P., Vallejo, R., 2007. Land-use history and fire effects on soil fertility in eastern Spain. Eur. J. Soil Sci. 58, 83-91.

Dupouey, J.L., Bachacou, J., Cosserat, R., Aberdam, S., Vallauri, D., Chappart, G., Corvisier de Villèle, M.A., 2007. Vers la réalisation d'une carte géoréférencée des 
forêts anciennes de France. Le Monde des Cartes 191, 85-98.

Dupouey, J.L., Dambrine, E., Laffite, J.D., Moares, C., 2002a. Irreversible impact of past land use on forest soils and biodiversity. Ecology 83, 2978-2984.

Dupouey, J.L., Sciama, D., Dambrine, E., Rameau, J.C., 2002b. La végétation des forêts anciennes. Revue Forestière Française 54, 521-532.

Dyer, J.M., 2010. Land-use legacies in a central Appalachian forest: differential response of trees and herbs to historic agricultural practices. Appl. Veg. Sci. 13, 195-206.

Falkengren-Grerup, U., ten Brink, D.J., Brunet, J., 2006. Land use effects on soil N, P, C and $\mathrm{pH}$ persist over $40-80$ years of forest growth on agricultural soils. For. Ecol. Manage. 225, 74-81.

Favre, C., Grel, A., Granier, E., Cosserat-Mangeot, R., Bachacou, J., Dupouey, J.L., 2013. Digitalisation des cartes anciennes. Manuel pour la vectorisation de l'usage des sols et le géoréférencement des minutes 1:40,000 de la carte d'Etat-Major (v. 12.7.3). INRA, Nancy p. 54.

Flinn, K.M., Vellend, M., 2005. Recovery of forest plant communities in post-agricultural landscapes. Front. Ecol. Environ. 3, 243-250.

Flinn, K.M., Vellend, M., Marks, P.L., 2005. Environmental causes and consequences of forest clearance and agricultural abandonment in central New York, USA. J. Biogeogr. 32, 439-452.

Fourchy, P., 1963. Les lois du 28 juillet 1860 et 8 juin 1864 sur le reboisement et le gazonnement des montagnes. Revue de géographie alpine 51, 19-41.

Gilbert, Y., 1989. Elevage, forêt et société. Analyse socio-historique. Forêt Méditerranéenne XI 203-216.

Girerd, B., Roux, J.-P., 2011. Flore du Vaucluse, troisième inventaire, descriptif écologique et chorologique. Biotope, Mèze (Collection Parthénope).

Goldberg, E., Kirby, K., Hall, J., Latham, J., 2007. The ancient woodland concept as a practical conservation tool in Great Britain. J. Nat. Conserv. 15, 109-119.

Gounod, M., 1969. Méthodes d'étude quantitative de la végétation. Masson éd., Paris.

Grime, J.P., 1973. Control of species density in herbaceous vegetation. J. Environ. Manage. 1, 151-167.

Hardy, B., 2017. Pre-industrial Charcoal Kiln Sites in Wallonia, Belgium: Spatial Distribution, Effects on Soil Properties and Long-term Fate of Charcoal in Soil. Catholic University of Louvain.

Hermy, M., Verheyen, K., 2007. Legacies of the past in the present-day forest biodiversity: a review of past land-use effects on forest plant species composition and diversity. Ecol. Res. 22, 361-371.

Honnay, O., Degroote, B., Hermy, M., 1998. Ancient-forest plant species in Western Belgium: a species list and possible ecological mechanisms. Belgian J. Bot. 130, 139-154.

Jackson, S.T., Sax, D.F., 2010. Balancing biodiversity in a changing environment: extinction debt, immigration credit and species turnover. Trends Ecol. Evol. 25, 153-160.

Janssen, P., Bec, S., Fuhr, M., Taberlet, P., Brun, J.-J., Bouget, C., 2018. Present conditions may mediate the legacy effect of past land-use changes on species richness and composition of above- and below-ground assemblages. J. Ecol. 106, 306-318.

Kaim, D., Kozak, J., Kolecka, N., Ziolkowska, E., Ostafin, K., Ostapowicz, K., Gimmi, U., Munteanu, C., Radeloff, V.C., 2016. Broad scale forest cover reconstruction from historical topographic maps. Appl. Geogr. 67, 39-48.

Kaplan, J.O., Krumhardt, K.M., Zimmermann, N., 2009. The prehistoric and preindustrial deforestation of Europe. Quatern. Sci. Rev. 28, 3016-3034.

Koerner, W., Dupouey, J.L., Dambrine, E., Benoit, M., 1997. Influence of past land use on the vegetation and soils of present day forest in the Vosges mountains, France. J. Ecol. 85, 351-358.

Kouba, Y., Martinez-Garcia, F., de Frutos, A., Alados, C.L., 2015. Effects of previous landuse on plant species composition and diversity in mediterranean forests. Plos One 10.
Legendre, P., Legendre, L., 1998. Numerical Ecology. Elsevier, Amsterdan.

Leyk, S., Boesch, R., Weibel, R., 2006. Saliency and semantic processing: extracting forest cover from historical topographic maps. Pattern Recogn. 39, 953-968.

MacDicken, K., 2012. Forest Resources Assessment Working Paper 2015. Terms and Definitions. Food and Agriculture Organization of the United Nations, Rome.

Mather, A.S., Fairbairn, J., Needle, C.L., 1999. The course and drivers of the forest transition: the case of France. J. Rural Stud. 15, 65-90.

Matuszkiewicz, J.M., Kowalska, A., Kozłowska, A., Roo-Zielińska, E., Solon, J., 2013. Differences in plant-species composition, richness and community structure in ancient and post-agricultural pine forests in central Poland. For. Ecol. Manage. 310, 567-576.

Oksanen, J., Blanchet, F.G., Friendly, M., Kindt, R., Legendre, P., McGlinn, D., Minchin, P. R., O'Hara, R.B., Simpson, G.L., Solymos, P., Henry, M., Stevens, H., Szoecs, E. Wagner, H., 2017. vegan: Community ecology package. R package version 2.4-4. https://CRAN.R-project.org/package = vegan.

Peterken, G.F., Game, M., 1984. Historical factors affecting the number and distribution of vascular plant-species in the woodlands of central Lincolnshire. J. Ecol. 72, $155-182$.

Pinheiro, J., Bates, D., DebRoy, S., Sarkar, D., Team, R.C., 2017. nlme: Linear and Nonlinear Mixed Effects Models.

Plue, J., Hermy, M., Verheyen, K., Thuillier, P., Saguez, R., Decocq, G., 2008. Persistent changes in forest vegetation and seed bank 1600 years after human occupation. Landsc. Ecol. 23, 673-688.

R Development Core Team, 2017. R: A Language and Environment for Statistical Computing. R Foundation for Statistical Computing, Vienna.

Salvaudon, A., Hamel, A., Grel, A., Rossi, M., Vallauri, D., 2012. Notice de la carte des forêts anciennes du Parc Naturel Régional du Lubéron $(1: 40,000)$ avec référence aux autres usages du sol. p. 18.

Sciama, D., Augusto, L., Dupouey, J.L., Gonzalez, M., Dominguez, C.M., 2009. Floristic and ecological differences between recent and ancient forests growing on non-acidic soils. For. Ecol. Manage. 258, 600-608.

Szabó, P., 2015. Historical ecology: past, present and future. Biol. Rev. 90, 997-1014.

Taillefumier, F., Piegay, H., 2003. Contemporary land use changes in prealpine Mediterranean mountains: a multivariate GIS-based approach applied to two municipalities in the Southern French Prealps. Catena 51, 267-296.

ter Braak, C.J.F., 1986. Canonical correspondence analysis: a new eigenvector technique for multivariate direct gradient analysis. Ecology 67, 1167-1179.

Tison, J.-M., Jauzein, P., Michaud, H., 2014. Flore de la France méditerranéenne continentale. Naturalia Publications, CBNMed, Turriers.

Valtinat, K., Bruun, H.H., Brunet, J., 2008. Restoration of oak forest: Effects of former arable land use on soil chemistry and herb layer vegetation. Scand. J. For. Res. 23, 513-521.

Varese, P., 1990. Pré-étude en vue d'une typologie des stations forestières du Luberon. In Parc Naturel Régional du Luberon, Apt, p. 141.

Vellend, M., Baeten, L., Myers-Smith, I.H., Elmendorf, S.C., Beauséjour, R., Brown, C.D., De Frenne, P., Verheyen, K., Wipf, S., 2013. Global meta-analysis reveals no net change in local-scale plant biodiversity over time. Proc. National Acad. Sci. U.S.A 110, 19456-19459.

Vuorela, N., Alho, P., Kalliola, R., 2002. Systematic assessment of maps as source information in landscape-change research. Landsc. Res. 27, 141-166.

Wulf, M., 2004. Plant species richness of afforestations with different former use and habitat continuity. For. Ecol. Manage. 195, 191-204.

Wulf, M., Sommer, M., Schmidt, R., 2010. Forest cover changes in the Prignitz region (NE Germany) between 1790 and 1960 in relation to soils and other driving forces. Landsc. Ecol. 25, 299-313. 